\title{
Socio-rhetorical interpretation: Theoretical points of departure ${ }^{1}$
}

\author{
Ernest van Eck ${ }^{2}$ \\ Research Associate: Department of New Testament Studies \\ University of Pretoria
}

\begin{abstract}
In the past two decades, narrative criticism (narratology) and social-scientific criticism have come to the fore as the two most prominent new methodologies to be associated with gospel research. When these two methodologies are integrated in the reading of biblical texts, this is now referred to as "socio-rhetorical interpretation". This article departs from a specific understanding of what is meant by a narratological reading of a text on the one hand and, on the other hand, by a social-scientific interpretation of biblical texts, in order to propose a working definition of a socio-rhetorical analysis of texts.
\end{abstract}

\section{INTRODUCTORY REMARKS}

As the $20^{\text {th }}$ century ends and the third millennium begin, narrative criticism and social scientific criticism have come to the fore as the two most prominent new methodologies to be associated with current gospel research. Moreover, literary approaches to the Gospels (e $\mathrm{g}$, narrative criticism) have now established themselves sufficiently for scholars studying the Gospels from a literary perspective not to need to fear losing what has been gained in the last two decades if they endeavour to integrate their work with social scientific criticism. According to Tannehill (1997:132), the need for this integra-

\footnotetext{
I It is a great pleasure to make a contribution to a volume dedicated to Prof Dr G M M Pelser. I first met Prof Pelser when I was a student, later - as part-time lecturer in the same Department - I came to know him better as a colleague, and, most pleasant of all, I came to know him as a friend whose door and heart was always open with sincere compassion. This article is dedicated to him, not only for what he taught me about the New Testament, but especially for his understanding, support and wisdom in times of personal strife and disappointment.

2 Dr Ernest van Eck (MA, DD) participated as research associate in the project "Biblical Theology and Hermeneutics", directed by Prof Dr A G van Aarde, Faculty of Theology, University of Pretoria.
} 
tion of methodologies is clear from a literary perspective: ancient texts can be read with understanding only if the reader has access to the "extratext" - a complex body of knowledge consisting, inter alia, of language codes, literary conventions, social codes and conventions, and cultural "scripts". In other words, the narrative texts of the Gospels are socio-historically and socio-culturally conditioned, and a methodology such as social scientific criticism of first-century Mediterranean society can help readers to understand this "extratext" (see Darr 1992:21-22).

Nowadays, the integration of narrative criticism with social-scientific criticism is referred to as "socio-rhetorical interpretation". However, the term "socio-rhetorical" is currently used in significantly different contexts, and different scholars are pursuing somewhat different goals with various strategies they consider to be socio-rhetorical in nature (Robbins 1998:284). This is also the case with regard to terms such as "social scientific criticism" (which is sometimes referred to as "sociological analysis", "sociohistorical analysis" or "cultural studies"), and "narrative criticism" ("narratology") which is sometimes referred to inter alia, as "rhetorical analysis" or "structural analysis". Some clarification of these terms is therefore urgently needed. An attempt to provide such clarification is made in the following section, whereafter a brief summary is given of the development and current state of socio-rhetorical interpretation.

\section{CLARIFICATION OF TERMS}

\subsection{Social-scientific criticism}

Whereas a scant decade ago most Gospel scholars were still engaged in the practice of historical criticism, social-scientific criticism has now emerged as one of the most prominent methods to be used in analysing texts. How does historical criticism differ from social scientific criticism?

The hallmark of the historical-critical method could be regarded as its emphasis on social context, the social conditioning and the social Sitz im Leben of biblical documents (Elliott 1991:2). Historical criticism, methodologically speaking, collects data from biblical texts to ascertain what was going on when and where. As such, historical criticism focuses on aspects of historical diachronic sequence in texts (in other words, on "historical worlds") and the social description thereof (Petersen 1985:18-19). Historical 
criticism also tends to focus on individual actors, extraordinary actions, distinctive properties, personal relationships and on the diachronic change of these aspects in texts. Historical criticism thus searches for what is unique and particular (Petersen 1985:18; Rohrbaugh 1987:24; 1991:68). As a result, historical criticism reduces social and cultural data in texts to mere illustrative background information.

According to Elliott (1989:1-2), the interests of historical criticism are helpful in the analysis of biblical texts, but they are not essential to the task of interpreting the social dynamics which generated biblical texts. What is lacking at the basis of the historical critical method is a process for ascertaining not only what the socio-historical situation of a given tradition or text was, but also "how and why these circumstances gave rise" to the production of biblical texts (Elliott 1989:3). Also, the notion that all ideas, concepts and knowledge (in texts) are socially determined, should be "taken into consideration much more and in a more socially scientific manner" (Van Aarde 1992:437), as has been the case in the historical-critical approach. The historical contexts of texts have broader social dimensions than only that "what was going on when and where". From a social scientific point of view, the contents of texts also refer to social behaviour involving two or more persons, social groups, social institutions, social systems, patterns, and codes. Furthermore, texts themselves are likewise shaped in their language, content and perspectives by the social systems in which they were produced: they serve as vehicles of social interaction. The contexts of these texts, are also social contexts, contexts shaped by societal conditions, structures and processes. In their content, structure, strategies and meaning, these texts presuppose and communicate information about the social systems of which they are a product. Therefore, what is needed to study biblical texts - beyond the mere collection of independent historical and social data - is a way to investigate the interrelationship of ideas and communal behaviour, belief systems and cultural systems and ideologies as a whole, and the relationship of such cultural systems to a natural and social environment, economic organization, social structures and political power. In short, what is needed is a social-scientific analysis of texts.

The social scientific study of biblical texts has two foci. First, social sciences are used to construct theories and models for collecting and analysing data, which illuminate salient features of ancient Mediterranean and early Christian society and culture. Second, it aims to elucidate the structure, content, strategy and intended rhetorical effect of the 


\section{Socio-rhetorical interpretation}

text within its social context. The text is analysed as a vehicle of communication whose genre, structure, content, themes and aims are shaped by the cultural and social dynamics of the social system and the specific historical setting in which the text was produced and to which it constituted a specific response (Elliott 1989:5-6).

Therefore, the most significant way in which a social scientific study of texts, differs from its "predecessor" - historical criticism - is that the social sciences focus on the sociology of narrative worlds, rather than on "historical worlds" (Petersen 1985:1819). It moves beyond social description to sociological analysis (Elliott 1989:2). This distinction between social description and sociological analysis also relates to a further difference between the historical critical method and a social scientific reading of a text: whereas historical critical analysis tends to focus on the individual, extraordinary, distinctive and personal, sociological analysis tends to focus on social groupings, regular, recurrent and routinized behaviour, common properties, systemic relations and structured patterns of behaviour (Elliott 1989:10-11). Historical criticism thus searches out what is unique and particular, while the social sciences are a generalising discipline $e^{3}$ (see also Rohrbaugh 1987:24; 1991:68). ${ }^{4}$

From the above description of social-scientific analysis, it is clear that socialscientific analysis also differs from approaches such as "social-history", "socio historical" and "cultural studies". Social-scientific analysis attempts to advance beyond "mere social description and inspired hunches concerning social relationships to social-scientific

3 According to Vorster (1988:46), historical-critical analysis is interested in reconstructing the social context in which a text genetically and mechanistically originated, while social scientific studies try to construct a social context in which the intended communication of a specific text could make sense. Seen in this way there is a discontinuity between previous historical-critical interpretation and a sociological analysis of texts. For Van Aarde (1988a:56), however, a sociological approach to biblical texts does not mean an abandonment of historical studies as such. It must rather be seen as an adaptation or restoration of the previous historical-critical approach. Van Aarde (1988a:56) formulates this as follows: historical criticism regards the text analytically as a phenomenon consisting of parts building up a whole. Modern biblical scholarship has adapted the more (analytical and fragmental) historical approaches into more "holistic" approaches, with the aim of trying to explain biblical truths to a new plural society. Current social scientific studies of the Bible and the biblical world should therefore be seen as an adaptation, and not as a replacement, of historical criticism.

4 "Biblical scholars, like most other historians, have been trained to look at the particular and unique. The social sciences, by contrast, seek the commonplace and generic. Their focus is not on details but generalizations. Neither their questions nor their answers are those of the historian" (Rohrbaugh 1991:69). 
analysis and description" (Elliott 1991:xix). ${ }^{5}$ The difference between a socio-historical method and a social scientific study of biblical texts therefore lies in the selfconscious employment of a social scientific method in order to analyse the text and context of biblical documents.

\subsection{Narrative criticism (narratology)}

Narrative criticism or narratology is a branch of literary criticism that has as its object the study of the formal features of narrative texts such as the Gospels. The formal features of narrative texts can (very briefly) be described as follows: ${ }^{6}$

The text (narrative world) is seen as a vehicle of communication between author and reader. Whether the author nor the reader of a text are not part of its narrative/ narrated world. Parts of the narrative world of the text are the characters in the story, the time in which the story occurs, as well as the settings that mark the time in which the characters act. Also part of that narrative world are the events that take place in the story. The events may be arranged in terms of time, place or topic, and may demonstrate cause and effect. To tell his or her story, the author employs a narrator (an implied author), to tell the story from a specific perspective (in the case of the Gospels, this perspective is called the narrator's theological point of view; see below). The implied author is part of the narrated world, since his or her perspective (point of view) can be detected from "how" the story is told. When the reader is able to identify/understand the narrator's point of view, the reader becomes the implied reader, that is, the reader that understands the "message" the narrator wants to put across by what and how he or she is narrating.

Each narraive has a plot (which normally consists of a beginning, a middle and an end). The plot of a narrative is constituted by different interrelations in the narrative,

\footnotetext{
${ }^{5}$ See Elliott (1989:18-24) for a description of the development of the sociological study of biblical texts and the biblical world, as this type of study moved from a socio-historical perspective to a social scientific perspective. Relating to this development, he also lists the main exponents and their respective works, classifying them either as socio-historical or social scientific in perspective and method. See also Van Staden's (1991:31-33) thorough discussion of the differences between social description/social history and sociological analysis. A similar discussion can also be found in Botha (1989:450-408) and Joubert (1991:39-54).

${ }^{6}$ Due to limitations of space and scope this description of narrative criticism/narratology is not very comprehensive. However, a vast amount of literature is available in this regard. A full discussion on characterization, the analysis of time and setting (aimed at unveiling and identifying the narrator's point of view) can, for example, be found in Van Eck $(1986,1988,1990,1991)$.
} 
such as the relationship between the implied author and the implied reader, the implied author and the narrator, the narrator and the narrated characters, and the narrator and the specific structures of time and place. ${ }^{?}$

One of the most important aspects of a text, in narrative criticism, is what is called the narrator's theological point of view. ${ }^{8}$ The narrator's theological point of view "enables one to get at the meaning of both the entire story and each episode within it" (Kingsbury 1997:3). It is "that principle around which the novel structures itself as form" (Carrol 1982:53), "the way the narrator sees the story" (Lubbock 1967:263). It is "a definite 'point', a definite idea or meaning, which, though it is never expressed explicitly, is felt almost by any reader" (Brooks 1959:27). It is the text's value system and complex of attitudes (Stevick 1967:18; that is, it is the ideological situation (perspective) from which the narrator tells his story (Chatman 1978:153).

The narrator's theological point of view, therefore, is what one could call the ideology ${ }^{9}$ of the text; or, to put it differently, it is "the ideological perspective from which the narrator/implied author observes the story-stuff of the narrative world and evaluates (selects and combines) it with the result that the narrated world is arranged in a plot as an orchestration to the ideal/implied reader" (Van Aarde 1986:63). If it is understood as such, the narrator's theological point of view/ideology can be defined as follows: Ideology is an integrated system of beliefs, assumptions and values (in terms of the symbolic universe), a network of themes and ideas (in terms of the text), representing an interpretation of the social reality (the macrosocial world of the text), intended to have meaning within a particular context (the microsocial world of the text). Ideology/ideological perspective thus has a pragmatic intention: its intended effect is either the legitimisation or the radical restructuring of the contextual world of its intended addressees. As such, the narrative text is not only seen as both the product and

\footnotetext{
7 "To know the plot is to understand how a story begins and respective conflicts arise, develop, and are resolved. Familiarity with plot enables one to appreciate the positioning of each episode within the story and the literary role this episode plays within the story as a whole" (Kingsbury 1997:3).

8 The theological point of view of the narrator is not the same as the perspective from which a story is told. The latter refers to the technical perspective or position - the angle of vision - from which the narrator is perceiving his or her story. Narrative point of view, on the other hand (as defined above), has to do with a network of themes and ideas that occur in a narrative as an "imagined" version of a particular reality.

9 For a description of the origins, as well as the development and usage of the term "ideology" in narrative criticism and the social sciences, see Van Eck (1995:96-118).
} 
the vehicle of ongoing social interaction, but it is also studied in terms of its communication, that is its intended social effect. ${ }^{10}$

When one reads a narrative text from a socio-rhetorical perspective, this definition operates as follows: the narrator of the Gospel interprets the symbolic universe and macrosocial world (contextual world) of its intended addressees in terms of certain beliefs, assumptions and values. This interpretation/reflection (the narrator's ideological perspective) is structured in the text by means of the technical perspective. The term "technical perspective" refers to the way in which the narrator uses characterization and structures time, events and space (setting) in the text in such a way that the reader is able to unravel the narrative point of view. The concept "narrative point of view" thus relates to

- the narrator's dialectical "understanding of his own, and intended readers'/hearers" current symbolic and social universes;

- a textual structuring thereof;

- with the aim of creating an intended effect on the addressees of the specific text, that is, either a legitimisation or a radical restructuring.

The ideological perspective of the narrator is thus a pragmatic matter: its pragmatic dimension is the narrator's aim to either legitimise the intended addressees' current understanding of the symbolic universe or to bring them to a different understanding of this symbolic universe and, as a consequence, to a different understanding of social structures in their contextual world. In that sense, the narrator's ideological perspective is the same as his or her interest(s).

\subsection{Socio-rhetorical analysis}

\subsubsection{The relationship between association of narrative and social-scientific analy-} sis: Current research in socio-rhetorical interpretation

Socio-rhetorical interpretation, as analysis and interpretation of social and cultural dynamics in written works, started with analyses of the relation of the we-passages in Acts to

10 For a description of the terms "symbolic universe", "social reality", "contextual world", "referential world", "macrosocial world" and "microsocial world", see Van Eck (1995:91-94). 
ancient Mediterranean sea voyages (Robbins 1975:5-18). This study by Robbins was followed up by his socio-rhetorical analysis of the learning-teaching cycle in Mark (Robbins 1981:97-114). In 1981, Elliott published his socio-rhetorical analysis of 1 Peter, as $A$ home for the homeless: A sociological analysis of 1 Peter, its situation and strategy. Elliott (1991:3) comments on the need for a socio-rhetorical analysis of texts as follows: "What is needed is a procedure for appropriating and applying sociological models and concepts which at each stage of the exegetical analysis could aid our understanding and interpretation of the interrelation of literary, theological and sociological aspects and dimensions of composition."

Elliott (1991:4) argues that the reason for the gap in the modern exegesis of biblical texts in terms of not attending to both sociological and literary aspects when reading texts, is that most readers fail to take into account the fact that all ideas, concepts and knowledge are socially determined. Also, many readers lack the stimulus or means for analysing the correlation or reciprocity between social realities and religious symbolizations. Although the historical critical school laid emphasis on some of these aspects (such as social context, social conditioning and the social Sitz im Leben) of biblical documents, what is lacking "is a process for ascertaining not only what the socio-historical circumstances of given traditions and compositions were but also how and why these circumstances gave rise to the productions under consideration" (Elliott 1991:3; his emphases).

One biblical exegetical model which is able to avoid these shortcomings is an approach which Elliott (1991:7) calls "sociological exegesis", which he defines as "the combined exercise of the exegetical and sociological disciplines, their principles, theories and techniques" (Elliott 1991:7-8). This approach is sociological in that it involves employing the perspectives, presuppositions, modes of analysis, comparative models, theories and research of the discipline of sociology. It is exegetical in that it focuses on a biblical document. By employing as many of the subdisciplines of exegesis as possible, it attempts to determine the impact of the text within various contexts. Furthermore, the primary goal of such an exegetical model is the interpretation of the text as it was designed to serve as vehicle of socio-religious interaction, that is, focusing especially on the questions of how and why the text was designed to function, and what its impact upon the lives and activities of its recipients was intended to be (Elliott 1991:8). The text is therefore seen mainly as an act of communication in a particular context or circum- 
stances. Taking the above into account, Elliott (1991:8) defines his "sociological exegesis" as follows: "Sociological exegesis is the analysis, interpretation, and synthesis (correlation) of ... the literary, sociological and theological features and dimensions of the text ... and this text's relation to and impact upon its narrower and wider social contexts."

Because texts are sociological both in content and in intent, that is, texts are both the products and the vehicles of ongoing social interaction, Elliott (1991:10) distinguishes between the strategy and the situation of texts. The strategy of a text is the "deliberate design of a document calculated to have a specific social effect on its intended hearers or readers". This can also be called the pragmatic dimension (or ideological/theological perspective) of a text by which the text is intended to serve as an effective medium of social interaction." The situation of the text, on the other hand, relates to the (historical) situation of the text (Elliott 1987:1). The situation of a text involves various levels. The macrosocial level of a text concerns the macrosocial context of the text, the total social system in which the text is produced. The microsocial level of a text concerns the more specific social conditions and features of its specific sender(s) and receiver(s).

According to Elliott (1991:11), this correlation between the strategy and the situation of a text establishes the integration of a literary and a social scientific analysis of the text. The strategy of a text is pursued by primarily literary methods (in the case of narratives, narratology), while the situation of a text is studied mainly by using models and theories from the social sciences.

In the 1991 paperback edition of $A$ home for the homeless, Elliott (1991:xix) redefined his "sociological exegesis" as "social science", or, more specifically, as "social scientific criticism" (Elliott 1991:xix). The reason for this is that the term "social science/social scientific criticism" embraces not only sociology (primarily the study of modern social systems), but also cultural anthropology (primarily the study of pre-

\footnotetext{
11 Elliott (1987:2) distinguishes several features that may serve as an appropriation of a text's strategy: A text

1. describes selected features conceming the situation (narrative world and social world), the sender(s) and receiver(s), and their relationship (the question of the relation of narrative world to social world);

2. emphasizes these selected features;

3. evaluates these selected features;

4. proscribes or criticizes and/or prescribes or praises certain actions, norms, sanctions, actors, traits, roles, institutions, attitudes, ideas, beliefs; and explains, justifies, and legitimates \# 1-4 and attempts to provide a plausible and persuasive rationale for the integration of experience and aspiration, group values and goals, lived reality and ideological implication.
} 
industrial social systems), economics, sociolinguistics, semiotics and other related subdisciplines of the social sciences field. ${ }^{12}$

Although Elliott applied his social scientific criticism to 1 Peter, he also states that, when this mode of analysis is applied to other writings of the New Testament, the variables will involve the specific document studied and the specifics of its genre, content and context. In such an analysis, the following questions will be important:

- Who are the explicated (or implied) readers and how is their situation portrayed (explicitly or implicitly) in the document? In other words, can a social profile of the audience be constructed?

- How are the reflection of and response to the situation presented in the document? This question relates to important matters such as how the document diagnoses and evaluates the situation, what criteria, norms and values are involved in such an evaluation, what kind of response to the situation is urged by the document, and also, whether any dominant symbols are used to characterize the identity and action of the audience and authors.

- What is the interpreter's analysis and explanation of the depiction, diagnoses and evaluation of the situation given in the document and the response it seeks of its audience?

- Who are the producers of this document as evident from either explicit or implicit internal information (see Elliott 1991:xxiv-xxv)?

The tasks and goals of social scientific criticism and literafy criticism are interrelated (Elliott 1991:xxxi). Both forms of criticism are necessary for the full exposure of both the social situation and the rhetorical strategies of a biblical text. Social scientific

\footnotetext{
12 Understood as such, social-scientific criticism is an expansion of the conventional historical-critical method, in that it complements other disciplines of the exegetical enterprise by means of its attention to the social dimensions of the text and its contexts of composition and reception. It differs from approaches labelled "social history" by attempting to advance beyond mere social description and "inspired hunches conceming social relationships" to social scientific analysis and description. Thus, it directs attention to the total constellation of factors (ecological, economic, educational, juridical, political, social and cultural [including religious]) shaping the context in of such selected material, the rhetorical design of the text and the capacity of the text as a meaningful and effective instrument of communication and social interaction (see Elliott 1991:xx). Which the text is produced. It also pays attention to why certain materials are selected and others are not, the arrangement of such selected material, the rhetorical design of the text and the capacity of the text as a meaningful and effective instrument of communication and social interaction (see Elliott 1997:xx).
} 
criticism ought to be accompanied by attention to linguistics and literary theory. Therefore, an exegetical approach should be developed that enables a methodological association of these two fronts - social science and literary theory.

The work of Petersen published in 1985 (Rediscovering Paul: Philemon and the sociology of Paul's narrative world) can also be regarded as a groundbreaking contribution with regard to the socio-rhetorical interpretation of biblical texts. According to Petersen (1985:1), the "map" of biblical studies looks different from a map drawn a decade ago, with two new routes on it, "one route is that of literary criticism and the other that of sociology". In his work on Philemon, he therefore attempts to "integrate contemporary literary and sociological capabilities into the traditional philological base of the historical-critical method" (Petersen 1985:ix). Petersen's methodological supposition presumes two important purposes: First, previous literary and sociological applications of these methods were inadequate, and second, the "method" he is proposing can be seen as building on the insights of the historical-critical approach. Petersen formulates his main reason for combining a literary and a sociological reading of the text as follows: "Worlds are human constructions, whether they are the constructions of societies or of narrators, and narrative worlds are comprised of the same kind of social facts - symbolic forms and social arrangements - as so-called real worlds. Thus narrative worlds can be studied like any other world" (Petersen 1985:ix; my emphases).

From this citation it is clear that, for Petersen, when using a "literary sociological method", three concepts are especially important, namely narrative worlds, symbolic forms and social arrangements. He defines these three concepts as follows: A narrative text consists of two "worlds"; a contextual world and a narrative world. The concept "contextual world" refers to the "notion of context with the time of writing" (Petersen 1985:7). The concept "narrative (referential) world", on the other hand, is that "reality which the narrator bestows upon his actors and upon their actions, a reality into which he authoritatively invites his audience" (Petersen 1985:7) ${ }^{13}$. The narrative world of a text is

13 The way in which the narrator invites his audience into the reality of the text's narrative or referential world is described by Petersen as follows: "The starting point of literary criticism ... is "to accept the form of the work' ...[O]ur Gospels ... have a narrative form ... and an imaginative world into which one can enter. How? By participating in the form of the work ... A literary reading of a narrative text ... begins at the moment when we allow ourselves to be addressed by its textually immanent narrator. That is the first step. All others follow from it ... the narrator lures the reader into ... times and places by perceptively locating himself and the reader in the midst of the scenes and events he describes, enabling the reader to see, bear and know things he would not have access to without the narrator's guiding voice. Through this device which literary critics call narrative point of view, the reader becomes a participant in the narrative form" (Petersen 1980:36-38). 
always a closed system, an internally ordered whole with an ultimate object of interest, thus a frame of reference (Petersen 1985:20). The relation between these two worlds, that is, the narrative world and the contextual world, is that the narrative world of a text is always a conceptual interpretation of the real, historical or contextual world. Narrative worlds can therefore also be seen as created texts of/from existing texts, or literary created worlds from existing worlds (see also Van Staden 1991:40).

The notions of social arrangements and symbolic forms are defined by Petersen (1985:x) as follows: "Social arrangements" have to do with the social structures underlying the social relations comprised by the actions of the actors. "Symbolic forms", on the other hand, have to do with the overarching cognitive systems, the systems of knowledge, belief, value, that define these actors' identities and motivate their actions. Social arrangements thus have to do with the social institutions one encounters in everyday life, institutions within the fields of economy, politics, education, kinship and religion. These elements make up the fabric that is known as the social universe or institutional order (cf Petersen 1985:28). This order is always a segmented one by virtue of its institutionality, and therefore needs to be integrated into a comprehensive and meaningful system. This is done by the symbolic universe, which is an all-embracing frame of reference which provides an integrating meaning for a society that consists of segmented institutions and diverse subjective experiences (see Van Staden 1988:349; 1991:61). The concept "symbolic universe" is defined by Petersen as a body of traditional knowledge known through symbols and language, as a system of meanings which defines and creates a "world", that is, real worlds, texts or narrative worlds.

In translating his understanding of these three concepts into his "literary sociological method", Petersen (1985:ix) uses and integrates the salient elements of narratology, cultural anthropology and the sociology of knowledge. Petersen's literary model is based on the "agreement that narrative or story is probably a universal means of understanding human social actions and relationships in time" (Petersen 1985:10). The formal coherence achieved by the narrativizing of experience (in other words, human social actions and relationships) is best represented in texts by three fundamental aspects of any 
narrative: point of view, plot and closure ${ }^{14}$, which order historical data, the values, and the belief systems of contextual worlds into narrative worlds.

Any narrative world is always an interpretation of the contextual world to which the narrative refers. The narrative world of a text is always a literary construction, and the events, which take place in such a world, always have a narrative quality, in that the narrative world is that reality which a narrator bestows upon his actors and upon their actions. The narrative world of a text, therefore, is a perspectival presentation (in terms of point of view) of the contextual world in which it is created. Worlds are always human constructions, whether they are constructions of societies or of narrators (Petersen 1985:ix) $)^{15}$.

The linking-up in Petersen's approach between his narratological and social scientific (using the theories of the sociology of knowledge) reading of the texts is

\footnotetext{
14 Point of view refers to the narrator's temporal, spatial and perspectival relationship to the story he is narrating. Temporally, point of view refers to the temporal relationship between the time of the narrator and the time referred to in the story. In terms of space as presented in texts, point of view refers to the spatial position of the narrator when he/she is telling about events in the same or different places, and, in terms of perspective, point of view refers to the narrator's principles or values in selecting some events for narration rather than others, or his ability to tell his audience the feelings, motives and thoughts in the story. Plot, on the other hand, refers to "the sequence of selected events as they appear in the story, regardless of whether this sequence corresponds to the sequence in which the events took place, or in which the narrator leads us to believe they took place. Finally, closure refers to the ending that fulfils the story, creates its coherence, and rounds off everything by satisfying expectations generated in the course of narration." (Petersen 1985:11-13).

is This insight is not only true in relation to the concepts of contextual worlds and narrative worlds, but is also one of the basic presuppositions of the sociology of knowledge. The primary aim of the sociology of knowledge is to analyse the social construction of reality, that is, the knowledge that determines conduct in everyday life. This presupposition of the sociology of knowledge is formulated by Berger \& Luckmann (1967:3) as follows: [I]nsofar as all human "knowledge" is developed, transmitted and maintained in social institutions, the sociology of knowledge must seek to understand the processes by which this is done in such a way that a taken-for "reality" congeals for the man in the street. According to this formulation, one of the major premises of the sociology of knowledge is that all thought is inextricably linked to its delineation by the contemporary historical situation and locality (Berger 1973:240). Because of this, Berger \& Luckmann (1967:4) see the central problem of the sociology of knowledge as establishing "the existential determination (Seinsgebundenheit) of thought as such" (Berger \& Luckmann 1967:4). Reality is therefore socially constructed, in that society is a product of man/human beings (Berger \& Luckmann 1967:1-3). Man, however, is also a product of society, in that society has a formative influence on man (Berger 1973:13-14). This means that, according to the sociology of knowledge, man's understanding of his symbolic universe precipitates into a social universe. This social universe consists of certain social institutions, which in turn are filled by social roles, "because by playing roles, the individual participates in a social world" (Berger \& Luckmann 1967:74). Society therefore necessarily has a routine character (Berger \& Berger 1976:16), because all human activity tends to become habitualized (Berger \& Luckmann 1967:53). This habitualization of human activity is the necessary precondition for the formation of institutions in society.
} 


\section{Socio-rhetorical interpretation}

therefore clear: narratologically speaking, any text consists of two "worlds", a contextual world and a narrative world, in which the narrative world is a construction/interpretation of the contextual world. The sociology of knowledge's presentation of reality boils down to the same relation between "worlds", in that the social universe (social historical reality) is always a constructed reality or interpretation of the symbolic universe. Simply put, the narrative world (as a construction in terms of a specific reflection on its contextual world) and the social universe (as a construction in terms of a specific reflection on the symbolic universe) are seen by Petersen as pertaining to the same thing, namely, con-structed worlds or realities. Petersen's combination of a narratological and social scien-tific reading of the text, in terms of constructed worlds and constructed realities, is also the reason for his employing of the results from studies done in the field of cultural anthropology (a subfield of social science anthropology) in his exegetical model ${ }^{16}$.

The relationship, therefore, between the worlds explored by anthropologists, exponents of the sociology of knowledge and analysts of narratives is that they study "worlds" mainly as "closed systems" (Petersen 1985:40). They study "worlds in worlds", in that narrative worlds, social worlds/universes and social arrangements respectively are always constructed from contextual worlds, symbolic universes and symbolic forms, and vice versa.

\section{Socio-rhetorical analysis: an energetic combination of narrative criticism and social scientific criticism}

From the above discussion of the respective methodological points of departure of Petersen and Elliott, it is clear that both argue that a combination of a literary and social scientific approach, methodologically speaking, is needed to read (biblical) texts in terms of the communication between author and reader in the specific context of the text

\footnotetext{
16 The main premise of cultural anthropology is that "worlds" must be seen as consisting of symbolic forms and social arrangements. From a cultural anthropological perspective, Malina (1986:11) describes "culture" as follows: "Culture, then, is a system of symbols, the result of a process of endowing persons, things, and events with meanings - with definition, delimitation, and situation in space and processes. A cultural group is a group of persons who share such a set of meanings and generally feel strongly about meanings shared within the group. The system of symbols thus becomes a system of meaning and feeling, a system of meaningfulness." Symbolic forms (as an overarching cognitive system or systenis of knowledge, belief and value) are thus built on or arise from the contextual world (Van Aarde 1992:438). The social arrangements within this world are mirrored in narrative worlds.
} 
produced. Petersen (1985:ix) calls his exegetical method "literary sociological", and his main reason for combining literary and social scientific models is to study the relation between symbolic forms (symbolic universe) and social arrangements (social universe). In stating that "narrative or story is probably a universal means of understanding human social actions and relationships in time" (Petersen 1985:10; see also Beidelman 1970:30; Kurz 1987:196; Van Aarde 1988b:238), and devoting a great deal of effort to defining the difference between narrative and contextual worlds, it is clear that Petersen is interested in the communication of texts in their specific context.

On the other hand, as has been shown above, Elliott (1991:7) calls his exegetical method "sociological exegesis" or "social scientific criticism" (Elliott 1991:xix). Elliott (1991:8) defines social scientific criticism as follows: "[T]he analysis, interpretation, and synthesis ... of ... the literary, sociological and theological features and dimensions of the text ... and this text's relation to and impact upon its narrower and wider social contexts". To put it simply, therefore, Elliott and Petersen are both interested especially in two aspects when reading a text: its communication, and the social context in which such communication takes place.

When one turns to narratology as an exegetical method, it is interesting to note that many similarities can be indicated between the definitions and objects of narratology as exegetical method and that of Petersen's "literary sociological" model and Elliott's "social scientific criticism". Also, looking at the following definitions of the narrative as textual genre, it soon becomes clear that two salient aspects of the narrative can be seen as its intended communication in an intended social context. "[A narrative can be seen as] a form of communication ... as the process [in which] a source ... sends as message ... along certain channels ... to some receiving individual or group ... in some situation ... in order to have some effect" (Rogers \& Shoemaker 1971:11; my emphases). "To explain this communicative act of the production of a text [a narrative] by its author, one must describe its meaning as it is constituted by the rule system the author wished the reader to apply and his intentions in producing the text. The meaning of this act of communication may, however, be lost if factors from the setting are not accounted for" (De Villiers 1984:67; his emphasis). 
Narrative exegesis need not disregard the historical situation within which a particular text communicates. Indeed, the survival and functioning of a text in its extratextual world makes the hermeneutic exercise possible. To escape the web of structuralism, the historical situation should be considered in a narratological theory, despite all obstacles. One must therefore adopt the viewpoint that a narrative involves a network of themes and ideas which are intended to have meaning within a particular context.

(Van Aarde 1988b:235; my emphases)

From these three citations, it can be argued that the salient features of narratology concur with Petersen and Elliott's exegetical models, in that both narratology and the two models of these two exegetes focus on the communication of narratives in a specific social context. Moreover, it concurs with what Robbins (1992:xix-xliv) calls a socio-rhetorical interpretation of biblical texts ${ }^{17}$. The socio-rhetorical interpretation of biblical texts can therefore be seen as an combination of a literary critical reading (narratological) and a social-scientific reading of the text, concentrating on the text's situation and strategy, as well as on the intended communication of the text as social force and social product.

To conclude: Socio-rhetorical readings of the Gospels emphasise the different worlds (contextual, referential and narrative) of the Gospels, as well as the relationship beween these worlds. Ideology/theology (as a specific understanding of the contextual world of a specific audience) leads to "new" narrative worlds (e g, the Gospels). Because of this, the situation and the strategy of the Gospels should come under scrutiny if any attempt is made to explore what the Gospels may have intended to communicate

\section{Works consulted}

Beidelman, T O 1970. The Kagur: A matrilineal people of East Africa. New York: Holt, Rinehart \& Winston.

Berger, P L 1973. The social reality of religion. Middlesex: Penguin Books.

17 Robbins (1992:xix) defines socio-rhetorical analysis as the interpretation of a text "according to inner texture [strategy - EvE], intertexture, social and cultural texture [situation - EvE], and ideological texture [theological/ideological point of view - EvE]". 
Berger, P L \& Berger, B 1976. Sociology: A biographical approach. Middlesex: Penguin Books.

Berger, P L \& Luckmann, T 1967. The social construction of reality: A treatise in the sociology of knowledge. New York: Doubleday.

Botha, J 1989. Sosio-historiese en sosiologiese interpretasie van die Nuwe Testament. Koers 54(5), 480-508.

Brooks, C 1959. Understanding fiction. New York: Appleton-Century-Croft.

Carrol, D 1982. The subject in question: The languages of theory and the strategies of fiction. Chicago: Chicago University Press.

Chatman, S 1978. Story and discourse: Narrative structure in fiction and film. Ithaca: Cornell University Press.

Darr, J A 1992. On character building: The reader and rhetoric of characterization in Luke-Acts. Louisville: Westminster Press.

De Villiers, P G R 1984. The interpretation of a text in the light of its socio-cultural setting. Neotestamentica $18,66-79$.

Elliott, J H 1987. Text, situation and strategy: Definitions and methodological considerations. Unpublished class notes composed for a course on "The early church in social-scientific perspective", University of San Francisco.

- 1989. Social-scientific study of the Bible and the biblical world. Unpublished paper delivered at an MDiv-seminar at the Department of New Testament Studies (Faculty of Theology, Sec A), University of Pretoria.

- 1991. A home for the homeless: A sociological analysis of 1 Peter, its situation and strategy. Minneapolis: Fortress Press.

Joubert, S J 1991. 'n Verruimde invalshoek tot die verlede? Die sosiaal-wetenskaplike benadering tot die Nuwe Testament. HTS 47, 39-54.

Kingsbury, J D (ed) 1997. Introduction, in Kingsbury, J D (ed), Gospel interpretation: Narrative-critical and social scientific approaches, 1-5. Harrisburg: Trinity Press International.

Kurz, W S 1987. New approaches to Luke-Acts. Biblica 68, 195-220.

Lubbock, P 1967. What is point of view? in Scholes, R E (ed), Approaches to the novel: Materials for poetics, 245-271. San Francisco: Chandler Publishing Company. 
Malina, B J 1986. Christian origins and cultural anthropology: Practical models for biblical interpretation. Atlanta: John Knox.

Petersen, N R 1980. Literary criticism in biblical studies, in Spencer, R A (ed), Orientation by disorientation: Studies in literary criticism and biblical literary criticism, 25-50. Pittsburgh: Pickwick.

- 1985. Rediscovering Paul: Philemon and the sociology of Paul's narrative world. Philadelphia: Fortress Press.

Robbins, V K 1975. The we-passages in Acts and the ancient sea voyages. $B R$ 20, 5-18.

- 1981. Summons and outline in Mark: The three-step progression. Novum Testamentum 23, 97-114.

- 1992. Jesus the teacher: A socio-rhetorical interpretation of Mark. Minneapolis: Fortress Press.

- 1998. Socio-rhetorical hermeneutics and commentary, in Mrazek, J, Dvorakova, R \& Brodsky, S, EPI TO AYTO: Essays in honour of Petr Pokorny, 284-297. Czech Republic: Mlyn.

Rogers, E M \& Shoemaker, F F 1971. Communication of innovations: A cross-cultural approach. New York: The Free Press.

Rohrbaugh, R L 1987. Models and muddles: Discussions of the social facets seminar. Forum 3(2), 23-34.

- 1991. BTB readers guide: The city in the second Testament. BTB 21(2), 67-75.

Stevick, P (ed) 1967. The theory of the novel. New York: The Free Press.

Tannehill, R C 1997. “Cornelius" and "Tabitha" encounter Luke's Jesus, in Kingsbury 1997:132-141.

Van Aarde, A G 1986. Plot as mediated through point of view: Mt 22:1-14 - a case study, in Petzer, J H \& Hartin, P J (eds), A South African perspective on the New Testament: Essays by South African scholars presented to Bruce M Metzger during his visit to South Africa in 1985, 62-75. Leiden: Brill.

- 1988a. Historical criticism and holism, in Mouton, J, Van Aarde, A G \& Vorster, W S (eds), Paradigms and progress in theology, 49-64. Pretoria: Human Sciences Research Council. 
Van Aarde, A G 1988b. Narrative point of view: An ideological reading of Luke 12:3548. Neotestamentica 22, 235-252.

- 1992. The Evangelium Infantum, the abandonment of children, and the infancy narrative in Matthew 1 and 2 from a social scientific perspective, in Lovering, E N (ed), Society of Biblical Literature: Seminar papers 1992, 435-453. Atlanta: Scholars Press.

Van Eck, E 1986. Die funksie van ruimte in die narratologie. HTS 42, 139-149.

- 1988. Galilea en Jerusalem as narratologiese ruimtes in die Markusevangelie: 'n Kontinuering van die Lohmeyer-Lightfoot-Marxsen-ketting. HTS 44, 139-163.

- 1990. Die ideologiese funksie van tyd en ruimte in die vertelkunde toegepas op die Markusvertelling. Ongepubliseerde MA-verhandeling. Universiteit van Pretoria.

- 1991. Die ideologiese funksie van ruimte in die Markusvertelling: 'n Verkenning. HTS 47, 1010-1041.

- 1995. Galilee and Jerusalem in Mark's story of Jesus: A narratological and socialscientific reading. Pretoria: Kital. (HTS, Supplementum 7.)

Van Staden, P 1991. Compassion - the essence of life: A social-scientific study of the religious symbolic universe reflected in the ideology/theology of Luke. Pretoria: Tydskrifafdeling van die Nederduitsch Hervormde Kerk van Afrika. (HTS Suppl 4.)

Vorster, W S 1988. Towards a post-critical paradigm: Progress in New Testament scholarship? in Mouton, J, Van Aarde, A G \& Vorster, W S (eds), Paradigms and progress in theology, 31-48. Pretoria: Human Sciences Research Council. 